\title{
飛翔体の同時会合問題における近似の無い最適誘導*1 Optimal Guidance on Simultaneous Attack by Multiple Missiles with No Approximation
}

\author{
有 田 俊 作 ${ }^{* 2} \cdot$ 上 野 誠 也*3 \\ Shunsaku ARITA and Seiya Ueno
}

Key Words : Guidance and Control, Missile, Impact Time Constraint, Field of Extremals

\begin{abstract}
In this paper, the optimal guidance strategy for simultaneous attack by multiple missiles is proposed; the strategy consists of following steps: (1) designation of optimal final impact time which is shared among all missiles participating in the simultaneous attack; (2) individual guidance of missiles by optimal control input which enable missiles to impact the target at the designated time. The optimization for this strategy is conducted on a non-linear model without linear approximation. Hence, although proposed strategy must be based on numerical optimization, optimal guidance of our strategy can be achieved by finite number of calculation. This is because all cases of optimal trajectories can be consolidated in finite set of normalized parameters by considering the necessary optimality conditions. Proposed strategy is effective for not only the missile guidance but also the cooperative control of multi vehicle systems.
\end{abstract}

\section{1.は じめに}

複数の飛翔体が同一の目標に同一の時間で会合すること を同時会合と呼ぶこととする。同時会合は, 以下の点で有 用である、まず, Jeon ら ${ }^{1)}$ が指摘するように, 同時会合に よって効率的な飽和攻撃が可能になる。また，同時会合の ための知見は近年盛んに研究されている協調システムの制 御にも応用が可能である。そこで本論文では, 最適な同時 会合を達成するための手法を提案する。

同時会合は, 次の 2 通りのアプローチにより達成できる. すなわち, 共通の会合時間を定め, それぞれの飛翔体をそ の時間で会合するように誘導するか，または，事前に会合 時間を決めず, 飛翔体間で現在の状況を通信し, 会合時間 を調整するかである，前者を個別誘導といい，後者を協調 誘導という ${ }^{2)}$. 本論文で提案する手法は個別誘導の考え方 に基づており，したがって最適な会合時間の決定方法と， 会合時間を指定可能な誘導則とから構成される.

同時会合にとって重要な要素である, 飛翔体の誘導則に

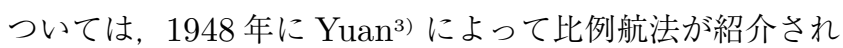
て以来, 多くの研究が行われている. 比例航法は, 線形化さ れた誘導問題において，目標が回避せず，遅れが無いとい う仮定のもと, 入力の二乗和を最小化する誘導法であるこ とが知られているが4), この結論を導いた枠組み(線形シス テムにおける二次形式評価関数に関する最適制御理論) を

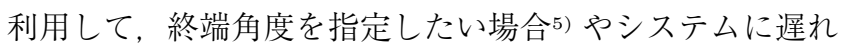

\footnotetext{
*1 C 2013 日本航空宇宙学会

平成 24 年 7 月 23 日原稿受付

$* 2$ 横浜国立大学環境情報学府

$* 3$ 横浜国立大学環境情報研究院
}

がある場合6)等，様々な目的に応じた最適誘導則を開発す ることが,この分野における研究の主流となっている。そし て, その成果の中には, 会合時間を指定可能な誘導則 $1,7,8)$ も含まれている。ここで, 線形化された誘導問題とは, 速 度が一定で, それに垂直な横加速度（すなわち方位角の変 化率）を入力とする飛翔体の，二次元平面における運動を 表したモデルにおいて, 各種角度が微少であるとして状態 方程式中の三角関数を除いたものによって構成される問題 である。線形化された誘導問題の枠組みで開発された最適 誘導則を同時会合に利用することを考えた時，この微少角 度の仮定が問題となる。つまり，会合時間の調整が必要な 時, 特に大きな時間延長が必要な時には, 飛翔体は目標に 直接向かわず, 角度をつけて飛行するため, 非線形性が強 まり，既存の最適誘導則は本来の性能が発揮できない. し たがって, 非線形な領域でも最適性が保たれるような, 会 合時間を指定可能な誘導則を開発することが必要である.

ところで Dubin ${ }^{9)}$ は，線形化される前の飛翔体モデルと 同様のモデルに関して, 入力に制限がある場合の最短経路 (最短時間) 問題を線形化によらずに解き, 最適軌道が曲 率半径最小の円弧（すなわち入力最大）と直線（無入力） によって構成されることを確認している。この結果はポン トリヤーギンの最大值原理によって一般的に説明すること ができ10), パターン化された最適軌道に関する知見は, 車 両11) や無人航空機12 14) などの対象に広く応用されている.

本論文でもDubin の問題にならい, 非線形なモデルによ る最適制御問題を考える。このことにより提案手法は, 先 に述べた線形化による問題を解決する。ただし，ここで考 える問題はD Dubinの問題とは異なり, 入力に制限の無い, 終端時間固定の最小入力問題である. 解析的に最適軌道を 


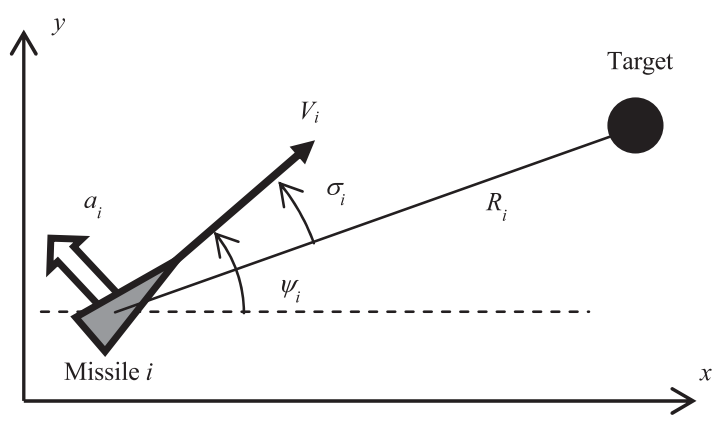

第 1 図 飛翔体のモデルと変数の定義

求めることは困難であるが，変分法から得られる最適性の 必要条件を検討すると, 最適軌道が二つの無次元パラメー 夕のみに依存することが明らかになる。依存するパラメー 夕が二つだけなので，これに関して数值最適化を網羅的に 行い，あらかじめすべての最適軌道を得て，記録しておく ことができる，提案手法は，数值最適化の結果の記録方法 やその扱い方を工夫し, 最適な同時会合に必要な, 最適会 合時間の決定および指定時間での最適誘導を達成する。具 体的には，最適な会合時間を決定する時，それぞれの飛翔 体の初期状態によって最適軌道の記録を有次元化して, 終 端時間と評価值の関係を調べ，それぞれの飛翔体の評価值 の和が最小となる終端時間を会合時間として指定する。ま た, その後の誘導では, 飛翔体の状態量を無次元化し, 最適 軌道の記録と比較することで，必要な最適入力を得る。な お, ここで誘導に用いる最適軌道の記録は, Bryson ら ${ }^{15)}$ の言う Field of Extremals に他ならない.

本論文は次のように構成される。次章では終端時間固定 の最小入力問題を定式化し, 最適軌道が二つのパラメータ のみに依存することを示す， 3 章では，最適な会合時間を 決定する方法を説明する。 4 章では, Field of Extremals を得，どのように誘導に使用するか説明する．最後に 5 章 で結論を述べる。

\section{2. 最適制御問題の定式化と最適性の必要条件}

2.1 飛翔体のモデルと状態方程式 本論文で想定する 飛翔体モデルを第 1 困に示す。目標は静止しているとする.

$i=1 \sim n$ の飛翔体が同時会合に参加すると想定し, 添 え字により区別する。第 1 図において， $x_{i}, y_{i}, \psi_{i}$ はそれ ぞれ, 位置座標と方位角を表す。飛翔体の速度 $V_{i}$ は一定で あるとし, 加速度入力 $a_{i}$ は速度べクトルに垂直な方向に 発生するとする。 また, 目標と飛翔体との距離を $R_{i}$, 速度 ベクトルと飛翔体から目標への目視線との角度差を $\sigma_{i}$ で 表す (方位角誤差と呼ぶ).

このモデルの状態方程式は, 次のように書ける.

$$
\begin{aligned}
& \dot{u}_{i}=-a_{i} \sin \psi_{i} \\
& \dot{v}_{i}=a_{i} \cos \psi_{i} \\
& \dot{\psi}_{i}=a_{i} / V_{i} \\
& \dot{x}_{i}=u_{i} \\
& \dot{y}_{i}=v_{i}
\end{aligned}
$$

ここで， $u_{i}$ 及び $v_{i}$ はそれぞれ速度 $V_{i}$ の $x$ 及び $y$ 方向成
分である。この状態方程式は，モデルの運動を記述するに は圥長な表現となっているが，このことは，2.3節において 最適性の必要条件を検討する際に都合が良い.

2.2 最適制御問題 上述の状態方程式を制約条件とし, 下の評価関数を最小化する入力 $a_{i}(t)$ を求めるような最適 制御問題を考える.

$$
j_{i}=\int_{0}^{t_{\mathrm{f} i}} a_{i}^{2} \mathrm{~d} t
$$

ここで終端時間 $t_{\mathrm{f} i}$ は目標に会合する時間で, あらかじめ指 定される。各飛翔体の初期時刻は 0 で共通だとする。初期 拘束条件は, $u_{i}(0)=V_{i} \cos \psi_{i 0}, v_{i}(0)=V_{i} \sin \psi_{i 0}, \psi_{i}(0)=$ $\psi_{i 0}, x_{i}(0)=x_{i 0}, y_{i}(0)=y_{i 0}$ である。ただし，任意に 与えられる初期の状態を添え字 0 で表す。終端拘束条件は $x_{i}\left(t_{\mathrm{f} i}\right)=x_{\mathrm{f}}, y_{i}\left(t_{\mathrm{f} i}\right)=y_{\mathrm{f}}$ であり, $x_{\mathrm{f}}, y_{\mathrm{f}}$ は目標の位置で, すべての $i$ (飛翔体) に共通である，ところで, 飛翔体の初期 位置が $x$ 軸上にあり, 目標が原点にあるような座標を設定し ても, 問題は一般性を失わない。この時, 目視線と $x$ 軸が一 致しているので, 初期方位角 $\psi_{i 0}$ は, 初期の方位角誤差 $\sigma_{i 0}$ と等しい. また，初期 $x$ 座標は目標までの初期の距離 $R_{i 0}$ に等しい. したがって初期拘束条件は， $u_{i}(0)=V_{i} \cos \psi_{i 0}$, $v_{i}(0)=V_{i} \sin \psi_{i 0}, \psi_{i}(0)=\psi_{i 0}=\sigma_{i 0}, x_{i}(0)=x_{i 0}=R_{i 0}$, $y_{i}(0)=0$ となり終端拘束条件は $x_{i}\left(t_{\mathrm{f} i}\right)=0, y_{i}\left(t_{\mathrm{f} i}\right)=0$ と なる。

この問題の最適解が満たすべき必要条件は, 二点境界值 問題となり，これを解析的に解くことは困難であるため, 本 論文では，上野16) が最適制御問題の求解に用いた数值解法 を用いて最適解を得る。次節では，最適軌道が二つの無次 元パラメータのみに依存することを示すが，これにより，一 つの最適軌道に，パラメータを同じくする他のすべての最 適軌道を代表させることができるので，限られた計算量で 最適軌道を網羅的に求めることができる。 また数值解法の 結果を代表軌道として記録しておけば，任意の最適軌道を 代表軌道の有次元化によって直ちに得ることができる.

2.3 最適性の必要条件 本節では最適性の必要条件 (オ イラーラグランジュ方程式）を変形して，最適軌道が二つ のパラメータに依存することを示す。なお本節では簡略化 のため, 添え字 $i$ を省略する。また, 速度 $V$ 及び終端時 間 $t_{\mathrm{f}}$ で各量を無次元化した場合の最適制御問題を考える. すなわち無次元の状態方程式は次のようになる。

$$
\begin{aligned}
& \frac{\mathrm{d} \tilde{u}}{\mathrm{~d} \tau}=-\tilde{a} \sin \psi \\
& \frac{\mathrm{d} \tilde{v}}{\mathrm{~d} \tau}=\tilde{a} \cos \psi \\
& \frac{\mathrm{d} \psi}{\mathrm{d} \tau}=\tilde{a} \\
& \frac{\mathrm{d} \tilde{x}}{\mathrm{~d} \tau}=\tilde{u} \\
& \frac{\mathrm{d} \tilde{y}}{\mathrm{~d} \tau}=\tilde{v}
\end{aligned}
$$

ここで, チルダは無次元量を表し, $\tau(0 \leq \tau \leq 1)$ は無次元 時間である，最小化すべき評価関数を次式とする. 


$$
\tilde{j}=\int_{0}^{1} \tilde{a}^{2} \mathrm{~d} \tau
$$

このシステムのハミルトニアンは

$$
\begin{aligned}
H= & \tilde{a}^{2}-\lambda_{\tilde{u}} \tilde{a} \sin \psi+\lambda_{\tilde{v}} \tilde{a} \cos \psi \\
& +\lambda_{\psi} \tilde{a}+\lambda_{\tilde{x}} \tilde{u}+\lambda_{\tilde{y}} \tilde{v}
\end{aligned}
$$

ここで, $\lambda$ は随伴変数で, 添え字は対応する状態量を表す. 随伴変数の微分方程式は，次のようになる，

$$
\begin{aligned}
\frac{\mathrm{d} \lambda_{\tilde{u}}}{\mathrm{~d} \tau} & =-\lambda_{\tilde{x}} \\
\frac{\mathrm{d} \lambda_{\tilde{v}}}{\mathrm{~d} \tau} & =-\lambda_{\tilde{y}} \\
\frac{\mathrm{d} \lambda_{\psi}}{\mathrm{d} \tau} & =\lambda_{\tilde{u}} \tilde{a} \cos \psi+\lambda_{\tilde{v}} \tilde{a} \sin \psi \\
\frac{\mathrm{d} \lambda_{\tilde{x}}}{\mathrm{~d} \tau} & =\frac{d \lambda_{\tilde{y}}}{\mathrm{~d} \tau}=0
\end{aligned}
$$

また, 随伴変数の終端值は, 2.2 節で述べた終端拘束条件 から， $\lambda_{\tilde{u}}(1)=\lambda_{\tilde{v}}(1)=\lambda_{\psi}(1)=0$ である. また, 式 $(6)$ から 明らかなように， $\lambda_{\tilde{x}}$ と $\lambda_{\tilde{y}}$ は未知の定数だが，この值は終 端を含む全区間で同じである，以上より直ちに，

$$
\begin{aligned}
& \lambda_{\tilde{u}}=\lambda_{\tilde{x}}(1-\tau) \\
& \lambda_{\tilde{v}}=\lambda_{\tilde{y}}(1-\tau)
\end{aligned}
$$

が言える。

ところで, $\tilde{a}$ が最適であれば，以下の式を満たす.

$$
\frac{\partial H}{\partial \tilde{a}}=2 \tilde{a}-\lambda_{\tilde{u}} \sin \psi+\lambda_{\tilde{v}} \cos \psi+\lambda_{\psi}=0
$$

この式は終端においても当然成り立つので，既知の終端值 を代入すると， $\tilde{a}(1)=0$ を得る。さらに式 $(8)$ を最適軌道 に沿って $\tau$ で微分し, 式 (3) と式 (6) を用いて整理すると, 以下のように最適入力の微分方程式が得られる.

$$
\frac{\mathrm{d} \tilde{a}}{\mathrm{~d} \tau}=0.5\left(-\lambda_{\tilde{x}} \sin \psi+\lambda_{\tilde{y}} \cos \psi\right)
$$

上式を $\tau=0 \sim 1$ で定積分すると，次式となる.

$\tilde{a}(1)-\tilde{a}(0)=0.5\left(-\lambda_{\tilde{x}} \int_{0}^{1} \sin \psi \mathrm{d} \tau+\lambda_{\tilde{y}} \int_{0}^{1} \cos \psi \mathrm{d} \tau\right)$

ここで， 2.2 節で導入した，飛翔体の初期位置が $x$ 軸上に あり，原点が目標である座標を考えると，飛翔体の速度が 一定と仮定しているので，次式が成り立つ。

$$
\begin{aligned}
& \int_{0}^{t_{\mathrm{f}}} V \cos \psi \mathrm{d} t=R_{0} \\
& \int_{0}^{t_{\mathrm{f}}} V \sin \psi \mathrm{d} t=0
\end{aligned}
$$

これを式 (10) に代入すると次式を得る.

$$
\tilde{a}(0)+0.5 \frac{R_{0}}{V t_{\mathrm{f}}} \lambda_{\tilde{y}}=0
$$

ところで, 式 (3)の $\psi$ に関する微分方程式と, 式 (6)の $\lambda_{\psi}$, $\lambda_{\tilde{x}}, \lambda_{\tilde{y}}$ に関する微分方程式及び式 (9) を連立させ, 次のよ うな 5 本の一階微分方程式を考える.ただし， $\lambda_{\psi}$ に関す る式は式 (7) によって書き換えている.

$$
\begin{aligned}
& \frac{\mathrm{d} \psi}{\mathrm{d} \tau}=\tilde{a} \\
& \frac{\mathrm{d} \lambda_{\psi}}{\mathrm{d} \tau}=(1-\tau) \lambda_{\tilde{x}} \tilde{a} \cos \psi+(1-\tau) \lambda_{\tilde{y}} \tilde{a} \sin \psi \\
& \frac{\mathrm{d} \lambda_{\tilde{x}}}{\mathrm{~d} \tau}=0 \\
& \frac{\mathrm{d} \lambda_{\tilde{y}}}{\mathrm{~d} \tau}=0 \\
& \frac{\partial \tilde{a}}{\partial \tau}=0.5\left(-\lambda_{\tilde{x}} \sin \psi+\lambda_{\tilde{y}} \cos \psi\right)
\end{aligned}
$$

2.2 節で述べた初期拘束条件と, これまでの議論から, $\psi(0)=\sigma_{0}, \tilde{a}(1)=0, \lambda_{\psi}(1)=0$ が言え, これは式 (13) の境界条件となっている。また，初期值を代入した式 (8) と式 (12) も式 (13)の境界条件となる．5 本の式に対し，5 個の境界条件が指定されるので, 初期から終端までの最適 入力 $\tilde{a}(\tau)$ が決まる。境界条件のうち, 任意に決定できるパ ラメータは $\sigma_{0}$ と $R_{0} / V t_{\mathrm{f}}$ であり, 最適入力はこの 2 数に 依存することがわかる。すなわち，

$$
\tilde{a}(\tau)=f\left(\sigma_{0}, \frac{R_{0}}{V t_{\mathrm{f}}}, \tau\right)
$$

ただし， $f$ は未知の関数である。本節の目的はあくまで, 最適入力が二つのパラメータによって決定することを示し, 以降に述べる数值最適化結果の取り扱いを容易にすること であり，式 (14) は，各時刻の最適入力を陽に与える式では ないことに注意されたい。

\section{3. 最適な会合時間の決定方法}

3.1 最適な会合時間 同時会合のための最適な会合時 間を以下のように定義する。すなわち，同時会合に関わる それぞれの飛翔体が, 設定された会合時間で, 最適（式 $(2)$ を最小化）に誘導された時に，それぞれの評価值の総和を 最小にするような時間とする．またこの時間を指定時間 $t_{\mathrm{d}}$ とする。 すなわち, 指定時間 $t_{\mathrm{d}}$ は, 飛翔体 $i$ の, ある $t_{\mathrm{f} i}$ における式 $(2)$ の最小值を $j_{\min , i}$ とし, その総和を

$$
J=\sum_{i=1}^{n} j_{\min , i}
$$

とした時，以下の式によって求まる。

$$
t_{\mathrm{d}}=\underset{t_{\mathrm{f}}}{\arg \min } J
$$

ここで，式 (16) における添え字の無い $t_{\mathrm{f}}$ は各飛翔体に共 通の終端時間である。つまり, 式 (16) は飛翔体が同時会合 することを前提としている。

3.2 数值最適化の結果の集約 無次元の最適入力と, $j_{\min , i}$ の関係は次式で与えられる.

$$
j_{\min , i} \frac{t_{\mathrm{f} i}}{V_{i}^{2}}=\int_{0}^{1} \tilde{a}_{i}^{2} \mathrm{~d} \tau
$$




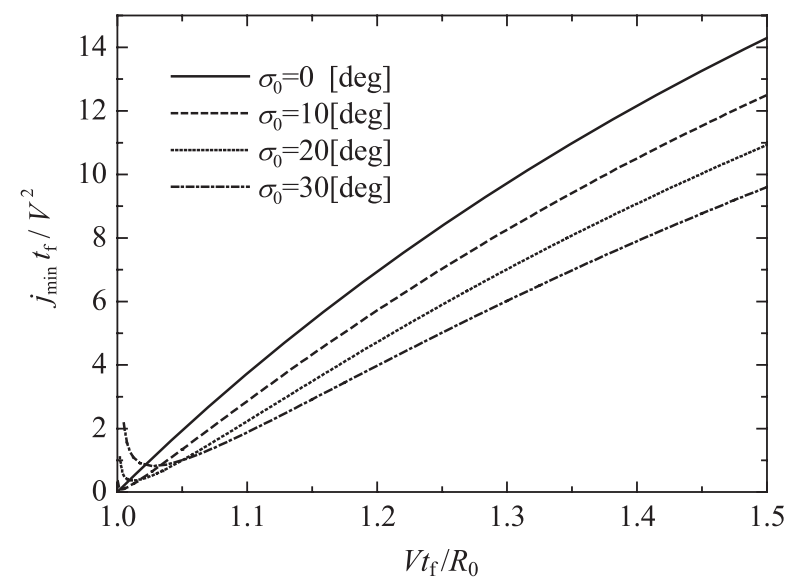

第 2 図 集約された数値最適化の結果

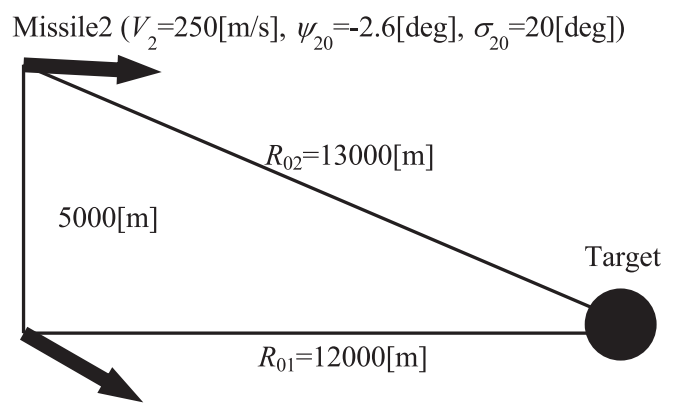

$\operatorname{Missile1}\left(V_{1}=300[\mathrm{~m} / \mathrm{s}], \psi_{10}=-30[\mathrm{deg}], \sigma_{10}=-30[\mathrm{deg}]\right)$

第 3 図 具体的な同時会合問題

式 (17) の右辺は, 式 (14) から明らかなように, $\sigma_{i 0}$ と $R_{i 0} / V_{i} t_{\mathrm{fi}}$ のみに依存する。式 (17) より以下が言える.す なわち, ある数值最適化の結果として評価值 $j_{\min , i}$ が得ら れたとすると, その無次元化量 $j_{\min , i} t_{\mathrm{fi}} / V_{i}^{2}$ は, 他の条件 $\left(V_{i}\right.$ や $\left.t_{\mathrm{fi}}\right)$ での最適化結果と一致する。 ただし, その場合 には $\sigma_{i 0}$ と $R_{i 0} / V_{i} t_{\mathrm{f} i}$ が一致していなければならない。さ らに言えば，適当な $V_{i}$ と $t_{\mathrm{f} i}$ について， $\sigma_{i 0}$ と $R_{i 0} / V_{i} t_{\mathrm{f} i}$ を変化させながらひとと扔りの数值最適化を行えば，その 結果は第 2 図に示すように二次元のグラフとして得られ, これは他のすべての条件 $\left(V_{i}\right.$ や $\left.t_{\mathrm{f} i}\right)$ における最適解とし て利用できる。 な扮第 2 図はすべての飛翔体に共通なので, 添え字 $i$ を省略している.

第 2 図を用いて, 式 (16) で定義される最適な同時会合時 間を決めることができる，次節では，具体例によってその 方法を説明する。

3.3 具体例 $i=1,2$ の飛翔体が同時会合を行うとす る。それぞれの飛翔体の初期位置や速度等は第 3 図に示す 通りである。

それぞれの飛翔体の速度 $V_{i}$, 初期の目標までの距離 $R_{i 0}$, 初期方位角誤差 $\sigma_{i 0}$ を用いて, 第 2 図を有次元化する。 こ の例では初期方位角誤差 $\sigma_{10}$ が負の值であるが，この時の 最適軌道は, 方位角誤差が正の場合の最適軌道と目視線を 挟んで対称な形状となり，入力で考えれば，正負が逆転す るだけである。したがって評価值の值は変化せず，第 2 図 の有次元化を考える際に，絶対值が同じ正の值を参照する

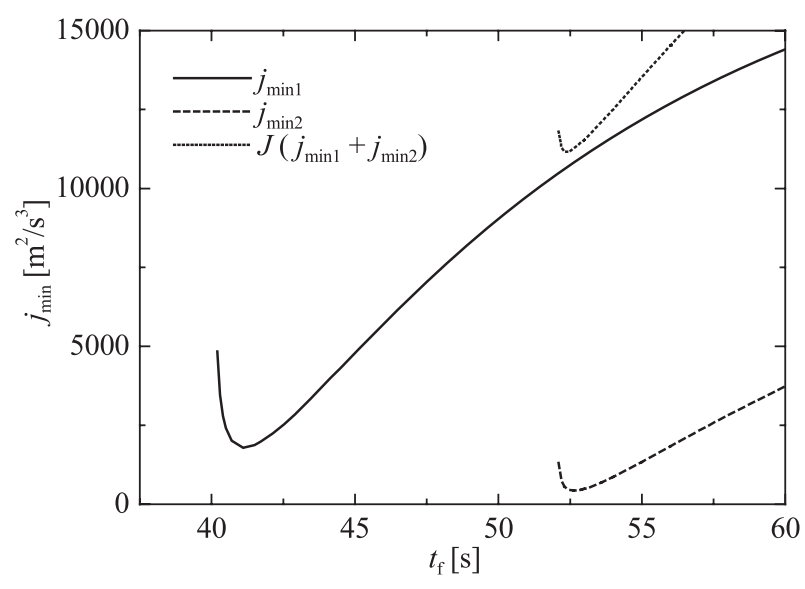

第 4 図 終端時間と評価值の関係

ことができる. 有次元化の結果得られるのが第 4 図であり， 終端時間と評価值（その終端時間における最適誘導結果） の関係を表している.

第 4 図から，飛翔体 1 にとっては $t_{\mathrm{f}}=41.1[\mathrm{~s}]$ が，飛翔 体 2 にとっては $t_{\mathrm{f}}=52.6[\mathrm{~s}]$ が, 最も入力量が少ない誘導 を達成できる終端時間であることがわかる，同時会合のた めには，飛翔体 1 にとってはその時間からの会合時間延長 が，飛翔体 2 にとっては会合時間短縮が必要になることが わかる。

第 4 図において点線で表されているのが，最小評価値の 和であり，式 (15) に対応している，定義（式 (16)）より， $J$ が最小值をとる時の $t_{\mathrm{f}}$ を指定時間とするので，点線の 極值を確認して, $t_{\mathrm{d}}=52.4[\mathrm{~s}]$ が求まる.

以上の手順は同時会合に参加する飛翔体の数が増えても 同じように適用できる。

本章での議論は，それぞれの飛翔体が最適に誘導される と仮定して，すなわち $j_{\min , i}$ を前提として進めた，次章で は, 指定時間 $t_{\mathrm{d}}$ が決められた時に, どのように最適な誘 導を実現するかについて述べる。

\section{4. 会合時間を指定可能な最適誘導}

4.1 最適性の原理 本節では, 最適性の原理を用いて, 式 (14) を変形することで, 状態量と最適入力を関連付ける. このことにより，数值最適化の結果を集約した図（Field of Extremals）を用いれば，最適な入力がフィードバック形 式で得られることが示される。

まず，ある最適軌道 $\mathrm{A}$ を想定し，最適軌道 $\mathrm{A}$ に関連す る量を添字で区別する，たとえば，最適軌道 A の初期の方 位角誤差と目標までの距離は $\sigma_{\mathrm{A} 0}, R_{\mathrm{A} 0}$ となる。なお，簡 単のため, 本節と次節では, 飛翔体を区別する添え字 $i$ を 省略する。最適軌道 A の最適入力は式 (14)より次のよう に与えられる。

$$
a_{\mathrm{A}}(t)=\frac{V}{t_{\mathrm{fA}}} f\left(\sigma_{\mathrm{A} 0}, \frac{R_{\mathrm{A} 0}}{V t_{\mathrm{fA}}}, \frac{t}{t_{\mathrm{fA}}}\right)
$$

飛翔体がある時刻 $t_{\mathrm{A}}\left(0 \leq t_{\mathrm{A}} \leq t_{\mathrm{fA}}\right)$ に達した時, その 時点での状態量を初期状態とする新たな最適制御問題を考 
え，その解を最適軌道 $\mathrm{B}$ として新たに定義する。すなわち， $\sigma_{\mathrm{B} 0}=\sigma_{\mathrm{A}}\left(t_{\mathrm{A}}\right), R_{\mathrm{B} 0}=R_{\mathrm{A}}\left(t_{\mathrm{A}}\right), t_{\mathrm{fB}}=t_{\mathrm{fA}}-t_{\mathrm{A}}$ である. 最 適軌道 $\mathrm{B}$ の最適入力は, 最適軌道 $\mathrm{A}$ と同じく, 式 (14) に より与えられる。

$a_{\mathrm{B}}(t)=\frac{V}{t_{\mathrm{fA}}-t_{\mathrm{A}}} f\left(\sigma_{\mathrm{A}}\left(t_{\mathrm{A}}\right), \frac{R_{\mathrm{A}}\left(t_{\mathrm{A}}\right)}{V\left(t_{\mathrm{fA}}-t_{\mathrm{A}}\right)}, \frac{t}{t_{\mathrm{fA}}-t_{\mathrm{A}}}\right)$

最適性の原理より, 最適軌道 $\mathrm{B}$ は最適軌道 $\mathrm{A}$ の一部分であ り, $a_{\mathrm{A}}(t)\left(t_{1} \leq t \leq t_{\mathrm{fA}}\right)$ と $a_{\mathrm{B}}(t)\left(0 \leq t \leq t_{\mathrm{fA}}-t_{\mathrm{A}}\right)$ が一 致するので, このうち時刻 $t_{\mathrm{A}}$ （最適軌道 $\mathrm{B}$ にとっては時 刻 0）に注目すると, 次式が成り立つ.

$$
\begin{aligned}
a_{\mathrm{A}}\left(t_{\mathrm{A}}\right) & =a_{\mathrm{B}}(0) \\
& =\frac{V}{t_{\mathrm{fA}}-t_{\mathrm{A}}} f\left(\sigma_{\mathrm{A}}\left(t_{\mathrm{A}}\right), \frac{R_{\mathrm{A}}\left(t_{\mathrm{A}}\right)}{V\left(t_{\mathrm{fA}}-t_{\mathrm{A}}\right)}, \frac{0}{t_{\mathrm{fA}}-t_{\mathrm{A}}}\right)
\end{aligned}
$$

式 (20) は任意の $t_{\mathrm{A}}\left(0 \leq t_{A} \leq t_{\mathrm{fA}}\right)$ 及び最適軌道について 成り立つので, $t_{\mathrm{A}}$ を $t$ に読み替え, 添え字を省略する。さ らに式 (20)の右辺に扔いて常に 0 となる部分を省略する と, 次式が成り立つ。

$$
\frac{a(t)\left(t_{\mathrm{f}}-t\right)}{V}=f\left(\sigma(t), \frac{R(t)}{V\left(t_{\mathrm{f}}-t\right)}\right)
$$

式 (21) は，会合までにかかる時間 $t_{\mathrm{f}}-t$ と速度 $V$ によって 無次元化された最適入力が, 同じ時刻の方位角誤差と, 無 次元化された目標までの距離によって決まることを示して いる.

\section{2 数值最適化の結果の集約 (Field of Extremals)}

式 (21) は，最適入力がフィードバックによって与えられる ことを示しているが, 式 (14)の説明で述べたように, 最適 入力が陽に算出できるわけではない，最適フィードバック 誘導を達成するためには，任意の状態量に対応する最適入 力をあらかじめ計算しておく必要があり，そのような最適 軌道の集まりを Field of Extremals という15). 本論文の場 合, 式 (21) から明らかなように, 無次元の最適入力は二つ の無次元パラメータに依存するので, このパラメータで張 られた二次元空間上に等高線として表すことができる，最 適軌道がなるべく均等にこの図上に配置されるように，適 当な初期条件を設定して一連の数值最適化を行うと, Field of Extremals が第 5 図のように得られる。

第 5 図において，実線は無次元パラメータで張られた空 間上の最適軌道を表し，飛翔体はこの軌道上を矢印の方向 へ移動する. 最適軌道の終端は必ず $R / V\left(t_{\mathrm{f}}-t\right)=1, \sigma=$ $0[\mathrm{deg}]$ なる点に収束するが, 初期状態は任意の点をとり得 る. 等高線は無次元化された最適入力を表す，誘導中の飛 翔体はその速度 $V$ や指定時間 $t_{\mathrm{f}}$, 目標までの距離 $R$ がい かなる值であっても，無次元化によって必ず第 5 図上の一 点に位置づけることができる，その場所に対応する無次元 最適入力（等高線）を読み取り，今度は逆にその值を有次 元化することで，その時実際に入力すべき最適值が求まる.

4.3 具体例 3.2 節と同じ問題設定で誘導シミュレーショ ンを行う，比較のため, 線形モデルを用いて開発された時間

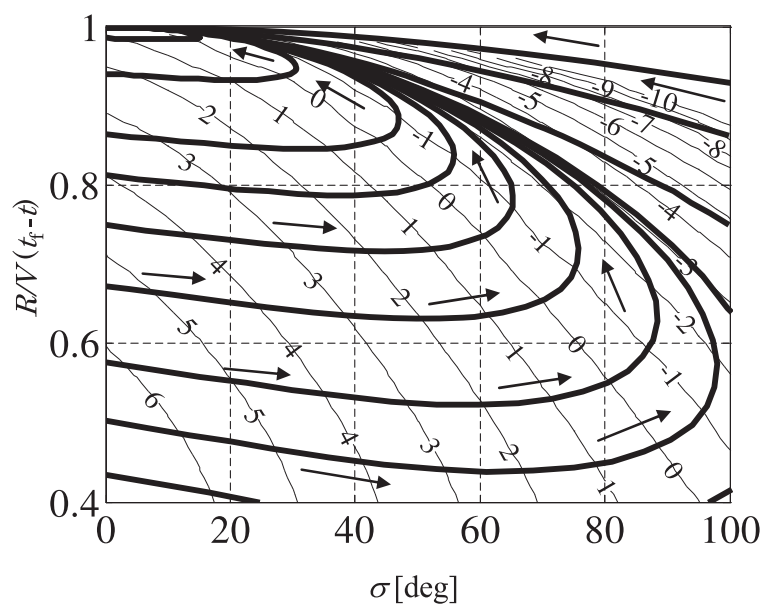

第 5 図 集約された最適解 (Field of Extremals) 等高線は無次元最適入力 $a\left(t_{\mathrm{f}}-t\right) / V$.

第 1 表 シミュレーション結果

\begin{tabular}{lc}
\hline 誘導則 & $j_{1}+j_{2}\left[\mathrm{~m}^{2} / \mathrm{s}^{3}\right]$ \\
\hline 提案手法 & 11162 \\
ITCG & 25693 \\
\hline
\end{tabular}

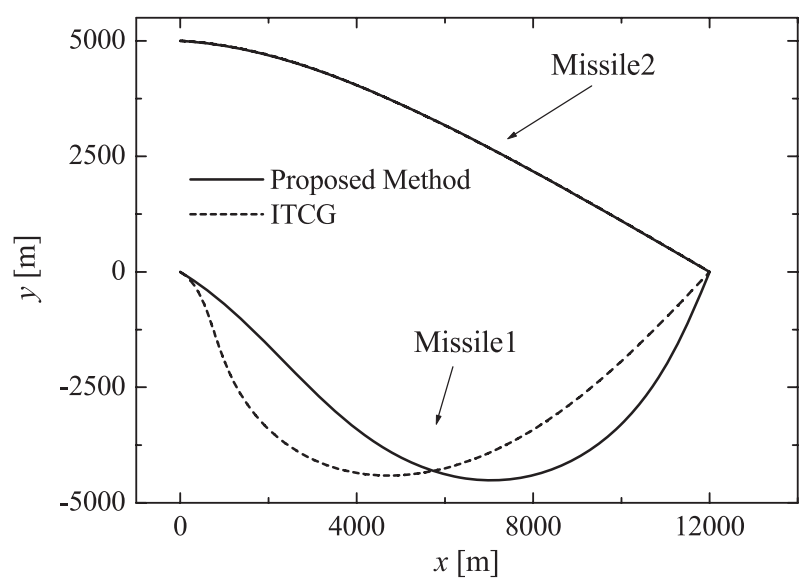

第 6 図 シミュレーション結果（軌道）

指定誘導則である, Impact-Time-Control Guidance Law $(\mathrm{ITCG})^{1)}$ による誘導結果も合わせて示す。指定時間は 3.2 節ですでに求めたように, $t_{\mathrm{d}}=52.4[\mathrm{~s}]$ であり, ITCGで も同じ指定時間を使用した。

シミュレーションの結果（評価値）は第 1 表のようになっ た，飛翔体の軌道を第 6 図に示し，それぞれの飛翔体の入力 の時間履歴を第 7 図及び第 8 図に示す。第 9 図では, 提案手 法によって誘導された飛翔体の軌道が, Field of Extremals 上でどのように推移するかを示す。

提案手法, ITCG ともに, 有意なミスディスタンス及び会 合時間誤差は無かった，第 1 表より，提案手法は ITCGに 比べて少ない制御努力量で目標を達成していることがわか る. 第 8 図に挍いて, ITCG の入力に認められる不連続は, 発散を防ぐために通常の比例航法に切り替わった時に生じ ている。第 6 図, 第 7 図から明らかなように, 提案手法と, ITCG で特に大きな差が出ているのが飛翔体 1 の誘導結果 である，本論文の飛翔体モデルは一定速度を仮定している 


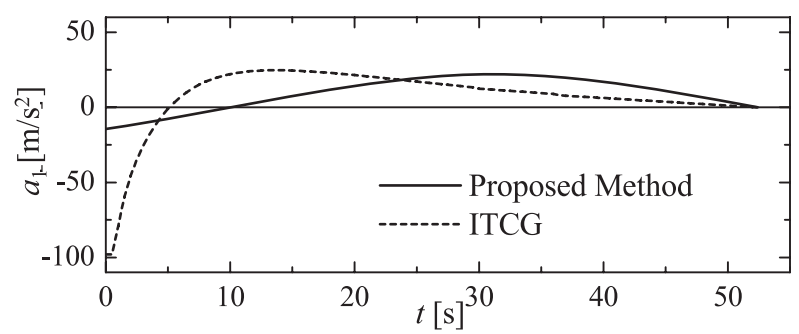

第 7 図 飛翔体 1 の入力

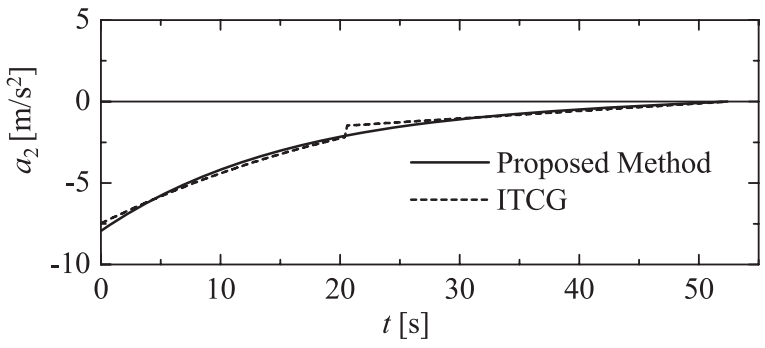

第 8 図 飛翔体 2 の入力

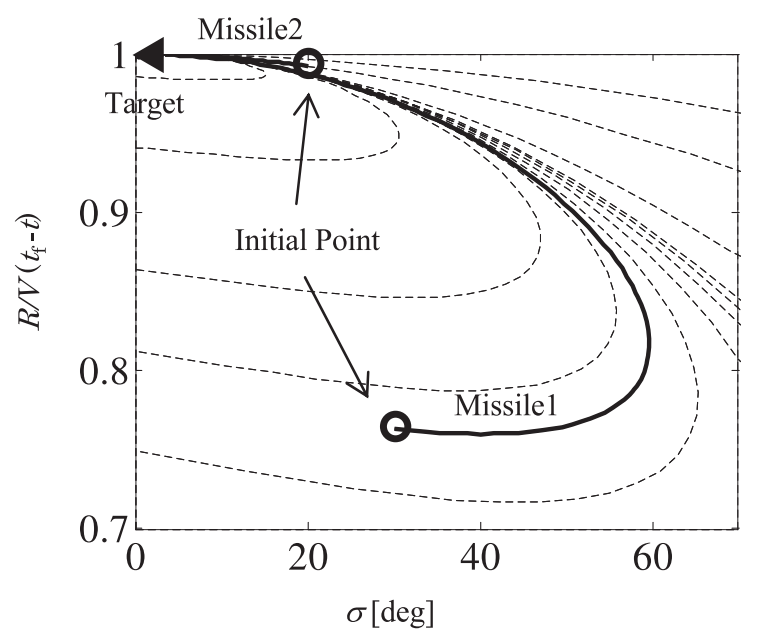

第 9 図 Field of Extremals 上の誘導結果

ので，仮に飛翔体 1 及び 2 が直線的に目標に向かったとす ると, その到達時間は初期条件から直ちに求まり, それぞ れ 40 秒と 52 秒である. 指定時間は 52.4 秒なので, 飛翔体 1 に，より大きな時間調整が必要となることがわかる。線形 モデルに基づいた ITCG による誘導では, 誘導初期の大き な入力によって時間調整を行い, 評価值を悪化させている ことがわかる。それに比べて提案手法による誘導では，よ り緩やかな誘導を達成できている。このことは実用上，横 加速度入力に起因する誘導抵抗を少なくすることに貢献し, 終端速度の増加や射程距離の延長等, 飛翔体にとって有利 な結果をもたらす。 また, 提案手法で求まる最適軌道は曲 率の二乗和が最小となる軌道なので, 一般の移動体にとっ ても追従が容易な軌道であり, 誘導分野における様々な応 用が考えられる。

\section{5. 結 論}

最適な同時会合を達成するための手法を提案した。本手
法は，最適な会合時間を指定する部分と，指定した時間で 目標に会合できるように飛翔体を誘導する部分から成る. 提案手法は飛翔体のモデルを線形化せずに用いているため, 線形化したモデルから導かれた既存の誘導則よりも，効率 的な誘導を達成することができる，その一方で，提案手法 は数值最適化に依存しなければならないが, 最適性の必要 条件を検討することで，計算量を最小限に抑え，数值最適 化を行うことの不利点を克服している.

今後の課題として，さらなる計算の簡略化に取り組む予 定である. 式 (9) は最適入力の微分方程式であり, 式中の 未知数は定数である。このことは元問題を常微分方程式の 初期值問題に変更できる可能性を示しており，これが達成 されれば，数值最適化によらず，少ない計算量で最適誘導 を達成できる。

\section{参 考 文 献}

1) Jeon, I. S., Lee, J. I. and Tahk, M. J.: Impact-Time-Control Guidance Law for Anti-Ship Missiles, IEEE Trans. Control Syst. Technol., 14 (2006), pp. 260-266.

2) Jeon, I. S., Lee, J. I. and Tahk, M. J.: Homing Guidance Law for Cooperative Attack of Multiple Missiles, J. Guid., 33 (2010), pp. 275-280.

3) Yuan, C. L.: Homing and Navigational Courses of Automatic Target-Seeking Devices, J. Appl. Phys., 19 (1948), pp. 11221128.

4) Nesline, F. W. and Zarchan, P.: A New Look at Classical vs Modern Homing Missile Guidance, J. Guid., 4 (1981), pp. $78-85$.

5) Kim, M. and Grider, K. V. : Terminal Guidance for Impact Attitude Angle Constrained Flight Trajectories, IEEE Trans. Aerospace Electr. Syst., 9 (1973), pp. 852-859.

6) Rusnak, I. and Meir, L.: Modern Guidance Law for HighOrder Autopilot, J. Guid., 14 (1991), pp. 1056-1058.

7) Lee, J. I., Jeon, I. S. and Tahk, M. J.: Guidance Law to Control Impact Time and Angle, IEEE Trans. Aerospace Electr. Syst., 43 (2007), pp. 301-309.

8）有田俊作，上野誠也：終端時間の指定が可能な飛翔体誘導則，第 29 回誘導制御シンポジウム資料, 2012, pp. 97-104.

9) Dubin, L. E.: On Curves of Minimal Length with a Constraint on Average Curvature, and with Prescribed Initial and Terminal Positions and Tangents, Am. J. Math., 79 (1957), pp. 497-516.

10) Soueres, P., Boissonnat, J. D. and Laumond, J. P.: Optimal Trajectories for Nonholonomic Mobile Robots, Robot Motion Planning and Control, Springer, London, 1998, pp. 93-170.

11) Moutarlier, P., Mirtich, B. and Canny, J.: Shortest Paths for a Car-Like Robot to Manifolds in Configuration Space, Int. J. Robotics Res., 15 (1996), pp. 36-60.

12) Anderson, E. P., Beard, R. W. and McLain, T. W.: RealTime Dynamic Trajectory Smoothing for Unmanned Air Vehicles, IEEE Trans. Control Syst. Technol., 13 (2005), pp. 471-477.

13) McGee, T. G. and Hedrick, J. K.: Optimal Path Planning with a Kinematic Airplane Model, J. Guid., 30 (2007), pp. 629-633.

14) McNeely, R. L., Iyer, R. V. and Chandler, P. R.: Tour Planning for an Unmanned Air Vehicle under Wind Conditions, J. Guid., 30 (2007), pp. 1299-1306.

15) Bryson, A. E. and Ho, Y. C.: Applied Optimal Control, Taylor and Francis, New York, 1975, pp. 128-147.

16) 上野誠也：フィードバック誘導制御則による航空機の最短時間旋 回, 日本航空宇宙学会誌，45 (1997), pp. 29-35. 